Tersedia Online di http://journal2.um.ac.id/index.php/jmsp/

ISSN Online : 2541-4429

\title{
PENINGKATAN KEMAMPUAN KEPALA SEKOLAH DALAM PENYUSUNAN PROGRAM SUPERVISI MELALUI PEMBINAAN BERKELANJUTAN
}

\author{
Kumala Ganti \\ Pengawas Sekolah Dinas Pendidikan Kecamatan Silangkitang \\ Jl. Besar Pandan Sari Desa Aek Goti Kec. Silangkitang Kab. Labuhanbatu Selatan \\ kumalagantis@yahoo.com
}

\begin{abstract}
The low ability of principals in the preparation of supervision programs is due to ignorance and lack of information about the procedures and preparation of good and correct supervision programs. To overcome these problems, school action research activities are carried out through continuous coaching activities with the aim of increasing the ability of principals in the preparation of supervision programs. The subjects in the study were 3 principals in Silangkitang Sub-district. Data collection techniques used are observation and documentation analysis. The data analysis used is the source and method triangulation technique. The results obtained from the initial conditions as many as 3 principals were declared unable to arrange well or $0 \%$ with an average value of 43.33 , increasing to 1 principal or $33.33 \%$ in the first cycle with an average value of 62.50 and $100 \%$ in the second cycle with an average value of 89.17 . The conclusion is that the continuous coaching carried out on 3 principals in Silangkitang Sub-district was stated to have succeeded in increasing the ability of principals in the preparation of supervision program.
\end{abstract}

Keyword: continuous coaching, supervision programs, principal

\begin{abstract}
Abstrak: Rendahnya kemampuan kepala sekolah dalam penyusunan program supervisi disebabkan karena ketidaktahuan dan kurangnya informasi tentang tata cara dan penyusunan program supervisi yang baik dan benar. Untuk mengatasi permasalahan tersebut maka dilaksanakan kegiatan penelitian tindakan sekolah melalui kegiatan pembinaan berkelanjutan dengan tujuan untuk meningkatkan kemampuan kepala sekolah dalam penyusunan program supervisi. Subyek dalam penelitian adalah 3 orang kepala sekolah di Kecamatan Silangkitang. Teknik pengumpulan data yang digunakan adalah observasi serta analisis dokumentasi. Analisis data yang digunakan adalah teknik triangulasi sumber dan metode. Hasil yang diperoleh dari kondisi awal sebanyak 3 kepala sekolah dinyatakan belum mampu menyusun dengan baik atau $0 \%$ dengan nilai rata-rata 43,33, meningkat menjadi 1 kepala sekolah atau $33,33 \%$ pada siklus pertama dengan nilai rata-rata sebesar 62,50 serta $100 \%$ pada siklus kedua dengan nilai rata-rata sebesar 89,17 . Kesimpulannya adalah pembinaan berkelanjutan yang dilakukan terhadap 3 orang kepala sekolah di Kecamatan Silangkitang dinyatakan berhasil meningkatkan kemampuan kepala sekolah dalam penyusunan program supervisi.
\end{abstract}

Kata kunci: pembinaan berkelanjutan, program supervisi, kepala sekolah

Untuk meningkatkan mutu pendidikan di Indonesia, pemerintah telah menetapkan UU Sistem Pendidikan. UU tersebut memuat 22 bab 77b pasal dan penjelasannya. UU Sistem Pendidikan (2003:38) menjelaskan bahwa setiap pembaharuan sistem pendidikan nasional untuk memperbaharui Visi, Misi, dan strategi pendidikan Nasional. Visi pendidikan Nasional diantaranya: (1) Mengupayakan perluasan dan pemerataan kesempatan memperoleh pendidikan yang bermutu bagi seluruh rakyat Indonesia, (2) Membantu dan memfasilitasi pengembangan potensi anak bangsa secara utuh sejak usia dini sampai akhir hayat dalam rangka mewujudkan masyarakat belajar, (3) Meningkat kesiapan masukan dan kualitas proses pendidikan untuk 
mengoptimalkan pembentukan kepribadian yang bermoral, (4) Meningkatkan kepropesionalan dan akuntabilitas lembaga pendidikan sebagai pusat pembudayaan ilmu pengetahuan, keterampilan, pengalaman, sikap, dan nilai berdasarkan standar nasional dan global, dan (5) Memperdayakan peran serta masyarakat dalam penyelenggaraan pendidikan berdasarkan prinsip otonomi dalam kontek Negara Kesatuan Republik Indonesia. Ada enam dimensi kompetensi pengawas satuan pendidikan yang telah disahkan oleh BSNP dengan Peraturan Menteri No. 12 tahun 2007 tentang Standar Kualifikasi dan Kompetensi Pengawas. Keenam dimensi kompetensi tersebut adalah kompetensi kepribadian, kompetensi sosial, kompetensi supervisi manajerial, kompetensi supervisi akademik, kompetensi evaluasi pendidikan dan kompetensi penelitian pengembangan.

Pengawas sekolah merupakan jabatan fungsional yang berlaku dalam lingkungan pendidikan formal. Peraturan Menteri Negara Pendayagunaan Aparatur Negara dan Reformasi Birokrasi Nomor 21 tahun 2010, pasal 1 ayat 2 menyebutkan pengawas sekolah adalah pegawai negeri sipil (guru) yang diberi tugas dan tanggung jawab dan wewenang secara penuh oleh pejabat yang berwewenang untuk melaksanakan pengawasan akademik dan manajerial pada satuan pendidikan. Pengawas Sekolah mempunyai dua tugas utama yaitu melaksanakan pembimbingan berkelanjutan dan supervisi akademik. Sedangkan, dua tugas utama seorang kepala sekolah, yaitu pengelolaan sekolah dan administrasi sekolah. Pengelolaan sekolah ialah proses perencanaan, pelaksanaan dan pengawasan seluruh sumber daya sekolah untuk mencapai tujuan sekolah secara efektif dan efisien. Sumber daya sekolah terdiri dari sumber daya manusia dan sumber daya lainnya.

Supervisi oleh pengawas sekolah terhadap kepala sekolah dan guru merupakan tugas dan tanggung jawab yang harus dilaksanakan secara rasional untuk membantu kepala sekolah dan guru dalam mengembangkan kompetensinya agar mengalami peningkatan kualitas diri. Oleh karenanya kemampuan serta kompetensi yang berkaitan dengan program supervisi menjadi bagian yang sangat penting bagi kepala sekolah dalam menjalankan tugasnya. Program supervisi menurut Purwanto (2007:76) adalah suatu aktivitas pembinaan yang direncanakan untuk membantu para guru dan pegawai sekolah lainnya dalam melakukan pekerjaan mereka secara efektif. Daradjat (1976:36) menjelaskan bahwa "Pembinaan adalah upaya pendidikan baik formal maupun nonformal yang dilaksanakan secara sadar, berencana, terarah, teratur dan bertanggung jawab dalam rangka memperkenalkan, menumbuhkan dan mengembangkan suatu dasar kepribadian yang seimbang utuh selaras".

Namun, dari 3 sekolah binaan yang menjadi wilayah binaan peneliti, berdasarkan hasil pengamatan peneliti sebagai pengawas sekolah terhadap kemampuan kepala sekolah dalam penyusunan program supervisi di sekolahnya masing-masing masih rendah. Hasil penilaian pada pra siklus menunjukkan bahwa belum ada kepala sekolah yang mendapat kriteria minimal baik, hanya terdapat 2 kepala sekolah atau $66,67 \%$ dalam kriteria kurang, dan 1 kepala sekolah atau $33,33 \%$ dalam kriteria cukup dengan rata-rata hasil penilaian sebesar 43,33 dengan kriteria kurang.Padahal kepala sekolah memiliki tugas dan tanggung jawab yang besar dalam penyusunan program supervisi. Realita di lapangan menunjukkan bahwa Kepala Sekolah "enggan" untuk melakukan tugas dan tanggung jawab dalam penyusunan program supervisi karena ketidaktahuan dan kurangnya informasi tentang tata cara dan pengelolaan terhadap administrasi sekolah yang baik dan benar. Oleh karena itu maka diperlukan upaya untuk meningkatkan penyusunan program supervisi melalui penelitian tindakan sekolah (PTS) yang akan dilakukan dengan kegiatan pembimbingan berkelanjutan.

\section{METODE}

Penelitian ini merupakan penelitian tindakan sekolah (School Action Research). Penelitian ini mengambil bentuk penelitian tindakan sekolah (PTS) yaitu kemampuan kepala sekolah dalam penyusunan program supervisi melalui pelaksanaan pembinaan berkelanjutan yang dilaksanakan dalam 2 siklus dan masingmasing siklus terdiri dari 4 tahap yaitu: perencanaan program tindakan, (2) pelaksanaan program tindakan, (3) pengamatan program, dan (4) refleksi. Untuk lebih jelas tentang proses 
pelaksanaan penelitian tindakan sekolah melalui pelaksanaan pembinaan berkelanjutan dapat dilihat pada Gambar 1.

Penelitian ini dilaksanakan di Kecamatan Silangkitang, Kabupaten Labuhanbatu Selatan. Waktu penelitian dilaksanakan selama 6 bulan mulai bulan Februari 2017 sampai dengan bulan Mei 2017. Subjek dalam penelitian ini adalah
3 orang kepala sekolah binaan peneliti yaitu kepala sekolah Kecamatan Silangkitang. Objek penelitian adalah peningkatan kemampuan kepala sekolah dalam penyusunan program supervisi melalui kegiatan pembinaan berkelanjutan. Data dikumpulkan melalui observasi dan analisis dokumentasi.

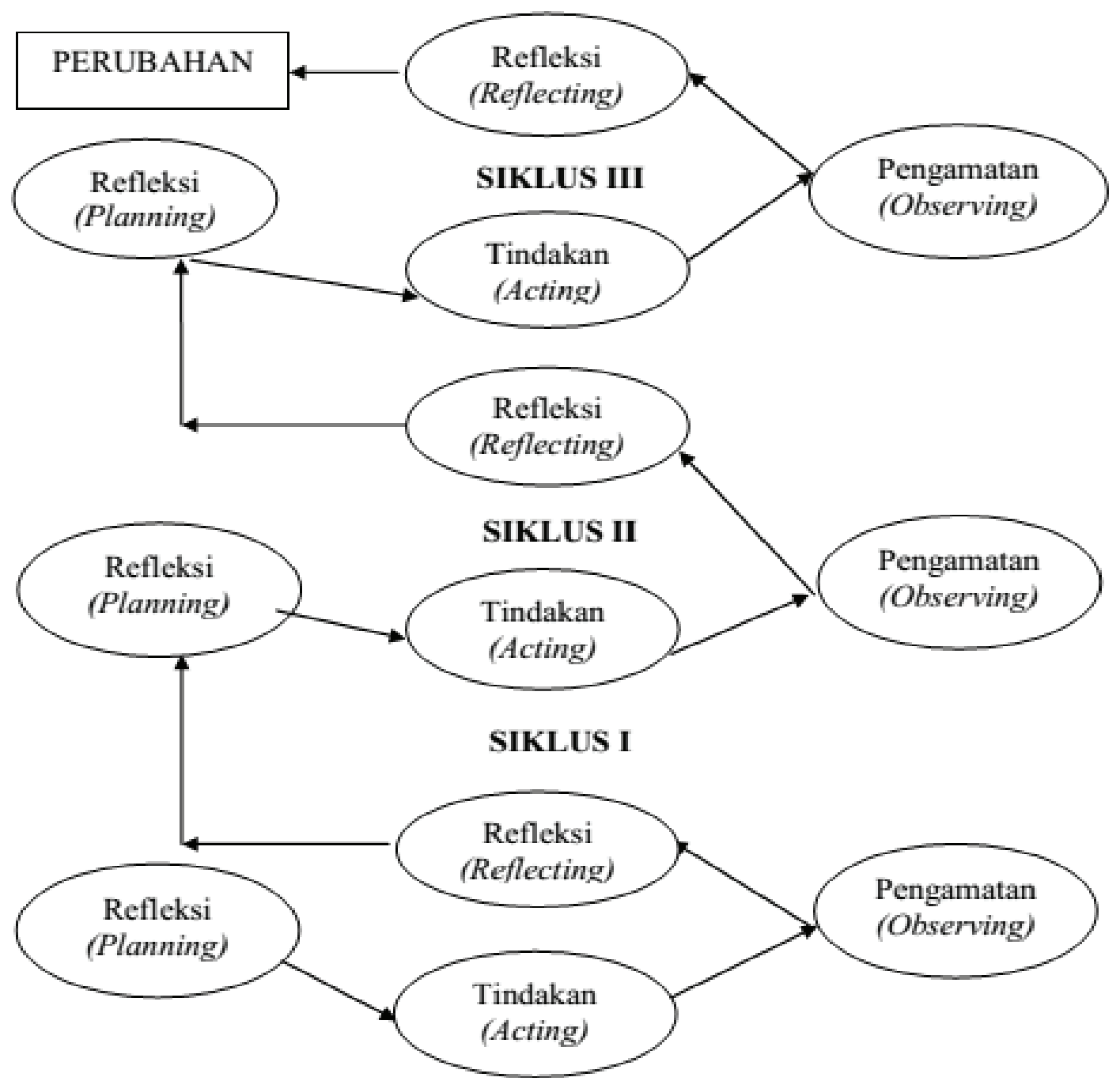

Gambar 1. Siklus Penelitian Tindakan Model Hopkins dalam Wiriatmadja (2005:145)

\section{HASIL}

\section{Hasil Siklus I}

Kegiatan perencanaan, kegiatan yang dilakukan antara lain sebagai berikut : 1) Menyusun jadwal kegiatan pelaksanaan penelitian yang akan dilakukan dengan kegiatan pembinaan berkelanjutan pada 3 sekolah den dengan menentukan hari, tanggal, jam dan tempat, dan 2) Menyiapkan materi kegiatan penelitian.
Pelaksanaan kegiatan pembinaan berkelanjutan dilaksanakan pada 3 sekolah dengan waktu dan tempat yang berbeda, sehingga perlu disusun jadwal kegiatan pembinaan berkelanjutan dan pelaksanaan kegiatan pembinaan berkelanjutan yang akan dilaksanakan. Ketiga sekolah tersebut adalah:

a) SDN SDN 118272 Aek Kulim

Dilaksanakan dalam 2 pertemuan yaitu pada tanggal 06 Maret 2017 dan 17 Maret 2017 dimulai 
dari pukul 10.00 sampai dengan jam 12.30 WIB.

b) SDN 115493 Aek Kulim

Dilaksanakan pada tanggal 10 Maret 2017 dan 20 Maret 2017 dimulai dari pukul 10.00 sampai dengan jam 12.30 WIB.

c) SDN 114360 Rintis

Dilaksanakan pada tanggal 13 Maret 2017 dan 14 Maret 2017 dimulai dari pukul 10.00 sampai dengan jam 12.30 WIB.

Adapun rincian kegiatan sebagaimana dijelaskan berikut ini: 1) Pengawas sekolah menjelaskan tujuan pemantauan (30 menit); 2) Diskusi dengan kepala sekolah tentang cara, teknik dan standar penyusunan program supervisi dan tidak lanjutnya; 3) Pengawas menjelaskan tentang prosedur penyusunan program supervisi yang baik dan benar sesuai dengan standar baku penyusunan program supervisi; 4) Diskusi dengan kepala sekolah tentang prosedur penyusunan program supervisi yang baik dan benar sesuai dengan standar baku penyusunan program supervisi; 5) Diskusi pengembangan penyusunan program supervisi yang baik dan benar sesuai dengan standar baku penyusunan program supervisi kepala sekolah; 6) Setelah selesai melaksanakan kegiatan diskusi, dilanjutkan dengan kegiatan penilaian berdasarkan lembar observasi terhadap program supervisi yang dimiliki oleh kepala sekolah; 7) Membuat kesimpulan tentang pengembangan strategi, penyajian materi, penyusunan program dan hasil pengembangan penyusunan program supervisi yang baik dan benar sesuai dengan standar baku penyusunan program supervisi; 8) Meminta bantuan kepala sekolah untuk mempersiapkan penyusunan program supervisi sesuai dengan hasil pembinaan pada siklus pertama untuk diberikan penilaian dan pembinaan lebih lanjut pada pelaksanaan siklus berikutnya; dan 9) Menutup kegiatan supervisi.

Hasil observasi tentang Program Pembinaan melalui kegiatan pembinaan berkelanjutan pada siklus I disajikan pada Tabel 1.

Tabel 1. Rekapitulasi Analisis Hasil Observasi Penyusunan Program Supervisi Pada Siklus Pertama

\begin{tabular}{ccccc}
\hline NO & $\begin{array}{c}\text { NAMA KEPALA } \\
\text { SEKOLAH }\end{array}$ & NILAI & $\begin{array}{c}\text { KRITERIA } \\
\text { NILAI }\end{array}$ & KET \\
\hline 1 & KS-1 & 50.00 & $\mathrm{C}$ \\
\hline 2 & $\mathrm{KS}-2$ & 67.50 & $\mathrm{C}$ \\
\hline 3 & $\mathrm{KS}-3$ & 70.00 & $\mathrm{~B}$ \\
\hline & Jumlah & $\mathbf{1 8 7 . 5 0}$ & - \\
\hline & Rata-Rata & $\mathbf{6 2 . 5 0}$ & $\mathrm{C}$ \\
\hline
\end{tabular}

Berdasarkan skor pada tabel di atas, dapat dijelaskan bahwa dari 3 orang kepala sekolah yang mengikuti kegiatan pembinaan berkelanjutan, 1 orang dinyatakan telah meningkat kemampuan dalam penyusunan program supervisi karena masuk dalam kriteria BAIK dengan perolehan nilai dalam rentan 70-89. Sedangkan 2 orang kepala sekolah dinyatakan belum meningkat kemampuan dalam pengelolaan administrasi kelas karena masuk dalam kriteria CUKUP dengan perolehan nilai dalam rentang 50-69, dan secara klasikal rata-rata mencapai nilai 62,50 sehingga masih dikategorikan dalam kriteria CUKUP.

Pelaksanaan kegiatan belajar mengajar diperoleh informasi dari hasil pengamatan bahwa ketidaktahuan kepala sekolah tentangkelengkapan program supervisi menjadi kendala utama dalam upaya peningkatan kemampuan penyusunan program supervisi, selain itu ketidaklengkapan program supervisi yang dipersiapkan kepala sekolah menunjukkan ketidaktahuan kepala sekolah tentang penyusunan program supervisi.

Pelaksanaan kegiatan penelitian tindakan sekolah dengan menerapkan pola pembinaan berkelanjutan pada siklus I ini masih terdapat kekurangan, sehingga perlu adanya revisi untuk dilakukan pada siklus berikutnya. Revisi yang dilakukan diantaranya dengan pemberian motivasi kepada kepala sekolah khususnya dalam penyusunan program supervisi yang dilakukan pengawas sekolah harus lebih intensif terutama 
dengan kegiatan pembinaan berkelanjutan serta bekerjasama dengan kepala sekolah dan guruguru untuk berusaha melengkapi seluruh bukubuku standar pada penyusunan program supervisi.

\section{Hasil Siklus II}

Rencana kegiatan awal pada siklus II seperti halnya dengan siklus I, yaitu peneliti menyusun jadwal kegiatan pelaksanaan penelitian yang akan dilakukan dengan kegiatan pembinaan berkelanjutan pada 3 sekolah dengan menentukan hari, tanggal, jam dan tempat, serta menyiapkan materi kegiatan penelitian.

Pelaksanaan kegiatan pembinaan berkelanjutan dilaksanakan pada 3 sekolah dengan waktu dan tempat yang berbeda, sehingga perlu disusun jadwal kegiatan pembinaan berkelanjutan dan pelaksanaan kegiatan pembinaan berkelanjutan yang akan dilaksanakan. Ketiga sekolah tersebut adalah:

a) SDN SDN 118272 Aek Kulim

Dilaksanakan pada tanggal 04 Maret 2017 dan 15 Maret 2017 dimulai dari pukul 10.00 sampai dengan jam 12.30 WIB.

b) SDN 115493 Aek Kulim

Dilaksanakan pada tanggal 08 Maret 2017 dan 18 Maret 2017 dimulai dari pukul 10.00 sampai dengan jam 12.30 WIB.

c) SDN 114360 Rintis

Dilaksanakan pada tanggal 11 Maret 2017 dan 22 Maret 2017 dimulai dari pukul 10.00 sampai dengan jam 12.30 WIB.

Adapun rincian kegiatan sebagaimana dijelaskan berikut ini: 1) Kepala Sekolah menjelaskan tujuan pemantauan (30 menit); 2) Diskusi dengan kepala sekolah membahas kelemahan dan kekurangan yang ada pada kegiatan siklus pertama; 3) Mengadakan tanya jawab seputar solusi dan pemecahan masalah yang menjadi kendala pada penyusunan program supervisi berdasarkan refleksi pada siklus pertama; 4) Pengawas menjelaskan tentang prosedur penyusunan program supervisi sesuai dengan standar baku penyusunan program supervisi yang harus dibuat oleh kepala sekolah berdasarkan revisi pelaksanaan siklus pertama; 5) Diskusi pengembangan dan penyusunan program supervisi yang baik dan benar sesuai dengan standar baku penyusunan program supervisi; 6) Setelah selesai melaksanakan kegiatan diskusi, dilanjutkan dengan kegiatan penilaian terhadap program supervisi yang dibuat oleh kepala sekolah berdasarkan lembar observasi penyusunan program supervisi; 7) Membuat kesimpulan tentang kegiatan pembinaan berkelanjutan tentang penyusunan program supervisi oleh kepala sekolah; dan 8) Menutup kegiatan supervisi.

Dari hasil observasi tentang program pembinaan melalui kegiatan pembinaan berkelanjutan pada siklus II disajikan pada Tabel 2.

Tabel 2. Rekapitulasi Analisis Hasil Observasi Penyusunan Program Supervisi Pada Siklus Kedua

\begin{tabular}{ccccc}
\hline NO & $\begin{array}{c}\text { NAMA KEPALA } \\
\text { SEKOLAH }\end{array}$ & NILAI & $\begin{array}{c}\text { KRITERIA } \\
\text { NILAI }\end{array}$ & KET \\
\hline 1 & KS-1 & 85 & B & \\
\hline 2 & KS-2 & 90 & SB \\
\hline 3 & KS-3 & 92.5 & SB \\
\hline & Jumlah & $\mathbf{2 6 7 . 5 0}$ & - \\
\hline & Rata-Rata & $\mathbf{8 9 . 1 7}$ & B \\
\hline
\end{tabular}

Berdasarkan skor pada tabel di atas, dapat dijelaskan bahwa dari 3 orang kepala sekolah yang mengikuti kegiatan pembinaan berkelanjutan, 3 orang kepala sekolah dinyatakan telah meningkat kemampuan dalam penyusunan program supervisi, dengan penjelasan 2 kepala sekolah dalam kriteria SANGAT BAIK dalam rentang $>=90$, dan 1 kepala sekolah dalam kriteria BAIK. Hal tesebut menunjukkan bahwa kemampuan kepala sekolah dalam penyusunan program supervisi meningkat cukup signifikan dari pelaksanaan kegiatan pada siklus-siklus 
sebelumnya. Dari hasil tersebut dapat disimpulkan bahwa pelaksanaan penelitian tindakan sekolah dinyatakan selesai dan tuntas pada siklus kedua karena semua indikator dan kriteria keberhasilan telah terpenuhi.

Pelaksanaan kegiatan belajar mengajar diperoleh informasi dari hasil pengamatan bahwa kegiatan pembinaan berkelanjutan yang dilakukan oleh peneliti terbukti efektif dalam meningkatkan kemampuan penyusunan program supervisi oleh masing-masing kepala sekolah binaan, peningkatan kemampuan penyusunan program supervisi tersebut dibuktikan dengan makin lengkapnya komponen-komponen penyusunan program supervisi yang telah disusun oleh masing-masing kepala sekolah, dan secara keseluruhan dapat disimpulkan bahwa penyusunan program supervisi oleh ke 3 kepala Sekolah binaan terbukti meningkat sesuai dengan indikator keberhasilan yang telah ditetapkan.

Pelaksanaan pembinaan berkelanjutan pada siklus II ini terjadi peningkatan yang signifikan terhadap peningkatan kemampuan kepala sekolah dalam menyusun dan mengelola program supervisi. Kenyataan ini membuktikan bahwa pelaksanaan pembinaan berkelanjutan sebagai upaya kemampuan kepala sekolah dalam menyusun dan mengelola program supervisi dinyatakan berhasil, sehingga proses perbaikan dihentikan pada pelaksanaan siklus kedua.

\section{PEMBAHASAN}

Keberhasilan tindakan ini disebabkan oleh peningkatan kemampuan kepala sekolah dalam menyusun dan mengelola program supervisi. Dengan meningkatnya kemampuan kepala sekolah dalam pengelolaan yang baik, maka pelaksanaan pembinaan berkelanjutan yang bersifat instruktif kepada para kepala sekolah di 3 Sekolah Binaan dapat mengoptimalkan kemampuan kepala sekolah dalam menyusun dan mengelola program supervisi.

Pelaksanaan pembinaan berkelanjutan sebagai wujud upaya peningkatan kemampuan kepala sekolah dalam menyusun dan mengelola program supervisi adalah pola pembinaan yang menjadi salah satu tugas wajib pengawas sekolah dalam usaha meningkatkan kemampuan manajerial secara menyeluruh tidak hanya kepala sekolah, tetapi juga para guru dan tenaga kependidikan lainnya pada sekolah yang bersangkutan.

Mengingat setiap kepala sekolah mempunyai permasalahan dalam menyusun dan mengelola program supervisi, maka kemampuan kepala sekolah dalam menyusun dan mengelola program supervisi mutlak diperlukan mengingat begitu vitalnya peran dan fungsi program supervisi sebagai penunjang baik dari segi kesiswaan maupun kepegawaian secara khusus. Kesesuaian persepsi tentang pentingnya menyusun dan mengelola program supervisi menjadi kunci pokok keberhasilan pelaksanaan kegiatan pembinaan yang dilakukan oleh peneliti yang berkolaborasi dengan kepala sekolah dengan didukung oleh semua sarana dan prasarana yang ada di sekolah.

Dalam bentuk tabel, peningkatan kemampuan kepala sekolah dalam penyusunan program supervisi pada kondisi awal sampai dengan pelaksanaan siklus kedua sebagaimana dijelaskan Tabel 3.

Tabel 3. Rekapitulasi Peningkatan Kemampuan Kepala Sekolah Dalam Penyusunan Program Supervisi pada Kondisi Awal, Siklus I dan Siklus II

\begin{tabular}{cccccccc}
\hline \multirow{2}{*}{ No } & Siklus & \multicolumn{2}{c}{ KS-1 } & \multicolumn{2}{c}{ KS-2 } & \multicolumn{2}{c}{ KS-3 } \\
\cline { 3 - 8 } & Nilai & $\begin{array}{c}\text { Kriteria } \\
\text { Nilai }\end{array}$ & Nilai & $\begin{array}{c}\text { Kriteria } \\
\text { Nilai }\end{array}$ & Nilai & $\begin{array}{c}\text { Kriteria } \\
\text { Nilai }\end{array}$ \\
\hline 1 & Awal & 30 & $\mathrm{~K}$ & 52.50 & $\mathrm{C}$ & 47.50 & $\mathrm{~K}$ \\
\hline 2 & Siklus I & 50 & $\mathrm{C}$ & 67.50 & $\mathrm{C}$ & 70 & $\mathrm{~B}$ \\
\hline 3 & Siklus II & 85 & $\mathrm{~B}$ & 90 & $\mathrm{SB}$ & 92.50 & $\mathrm{SB}$ \\
\hline
\end{tabular}


DalambentukgrafikRekapitulasiPeningkatan Kemampuan Kepala Sekolah Dalam Penyusunan Program Supervisi pada Kondisi Awal, Siklus
I dan Siklus II sebagaimana dijelaskan pada Gambar 1.

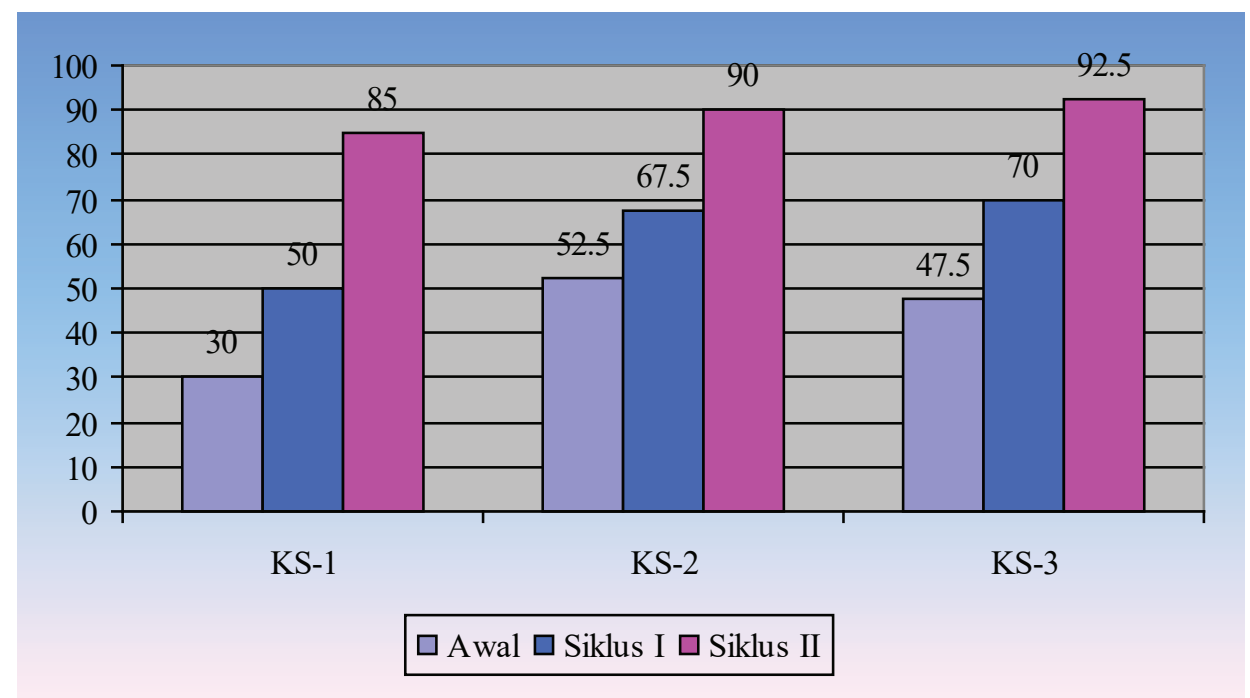

\section{Gambar 1. Peningkatan Penilaian Kemampuan Kepala Sekolah dalam Penyusunan Program Supervisi pada Kondisi Awal, Siklus I dan Siklus II}

Terbukti bahwa terjadi peningkatan kemampuan penyusunan program supervisi oleh masing-masing kepala sekolah di 3 sekolah binaan. Hal tersebut menunjukkan bahwa pelaksanaan pembinaan berkelanjutan terbukti efektif dalam meningkatkan kemampuan penyusunan program supervisi.

Kesimpulan akhir dari pelaksanaan kegiatan pembinaan berkelanjutan terhadap penyusunan program supervisi membuktikan bahwa administrasi dalam pendidikan yang tertib dan teratur, sangat diperlukan untuk meningkatkan kemampuan pengelolaan pendidikan bagi Kepala Sekolah. Peningkatan kemampuan tersebut akan berakibat positif, yaitu makin meningkatnya efisiensi, mutu dan perluasan pada kinerja di dunia pendidikan tersebut. Untuk memperlancar kegiatan di atas agar lebih efektif dan efisien perlu informasi yang memadai. Sistem informasi di dunia pendidikan ini menyangkut dua hal pokok yaitu kegiatan pencatatan data (recording system) dan pelaporan (reporting system).

Administrasi suatu lembaga pendidikan merupakan suatu sumber utama manajemen dalam mengatur proses belajar mengajar dengan tertib sehingga tercapainya suatu tujuan terpenting pada lembaga pendidikan tersebut. Yang sangat diperlukan oleh para pelaku pendidikan untuk melakukan tugas dan profesinya. Kepala Sekolah dan guru di sekolah sangat memerlukan data-data tentang siswa, kurikulum, sarana dan sebagainya untuk pengelolaan sekolah sehari-hari. Pengawas pendidikan di semua tingkat memerlukan datadata tersebut sebagai bahan sarana supervisi. Untuk tingkat yang lebih tinggi misalnya Dinas Penididikan mulai tingkat kecamatan sampai propinsi memerlukan data untuk pelaporan yang lebih tinggi, untuk melakukan pembinaan, serta untuk menyusun rencana atau program pendidikan pada masa mendatang. Di tingkat pusat (nasional) data pendidikan diperlukan untuk perencanaan yang lebih makro, melakukan pembinaan, pengawasan, penilaian (evaluasi), dan keperluan administrasi lainnya.

Data pendidikan yang terdapat disekolah sangat banyak macam dan jenisnya. Ada yang bersifat relatif tetap dan ada yang selalu berubah. Untuk mendapatkan gambaran perubahan data dari waktu ke waktu, perlu dilakukan pencatatan yang teratur dan berkelanjutan dengan menggunakan sistem yang baku dalam satu sistem. Agar pencatatan data lebih akurat dan benar sesuai yang diharapkan tenaga administrasi yang terampil dan mengetahui apa yang menjadi tugasnya.

Di lembaga pendidikan tingkat menengah hampir sebagian besar belum ada tenaga administrasi sesuai yang diharapkan. Kepala 
Sekolah sebagai administrator di lingkungan sekolah yang dipimpinnya, dalam melaksanakan tugas administrasi dibantu oleh guru dengan cara membagi tugas administrasi mereka. Agar dalam melaksanakan tugas administrasi dan pelaporan, cepat dan benar diperlukan pedoman administrasi di tingkat sekolah.

\section{SIMPULAN DAN SARAN}

\section{Simpulan}

Berdasarkan hasil penelitian tindakan yang dilakukan dalam upaya meningkatkan kemampuan kepala sekolah dalam menyusun program supervisi mellaui kegiatan pembinaan berkelanjutan diperoleh kesimpulan bahwa: Model pembinaan peningkatan kemampuan kepala sekolah dalam penyusunan program supervisi dengan pelaksanaan pembinaan berkelanjutan terbukti mampu meningkatkan kemampuan kepala sekolah dalam penyusunan program supervisi di 3 sekolah binaan sehingga diperoleh suatu pengalaman baru dalam penyelenggaraan model pembinaan terhadap peningkatan kemampuan kepala sekolah dalam penyusunan program supervisi yaitu dengan pelaksanaan pembinaan berkelanjutan.

\section{Saran}

Berdasarkan kondisi awal, siklus I hingga siklus II disimpulkan bahwa telah terjadi peningkatan kemampuan kepala sekolah dalam penyusunan program supervisi di 3 sekolah binaan. Hasil menunjukkan bahwa terjadi peningkatan kemampuan para kepala sekolah secara signifikan setelah dilaksanakan kegiatan pembinaan dengan kegiatan pembinaan berkelanjutan. Hal tersebut dapat dilihat pada hasil yang diperoleh, yaitu dari kondisi awal sebanyak 3 kepala sekolah dinyatakan belum mampu menyusun dengan baik atau $0 \%$ dengan rata-rata penilaian 43,33 , meningkat menjadi 1 kepala sekolah atau 33,33\% pada siklus pertama dengan hasil rata-rata nilai sebesar 62,50 serta $100 \%$ pada siklus kedua dengan perolehan nilai rata-rata sebesar 89,17. Penjelasan mengenai kriteria nilai dari kondisi awal adalah kurang, meningkat menjadi cukup dan baik pada siklus terakhir.

\section{DAFTAR RUJUKAN}

Daradjat, Zakiyah. 1976. Ilmu Jiwa Agama. Jakarta: Bulan Bintang.

Depdiknas. 2003. Undang-Undang Nomor 20 Tahun 2003 tentang Sistem Pendidikan Nasional. Jakarta.

Depdiknas. 2007. Peraturan Menteri Pendidikan Nasional Republik Indonesia Nomor 12 Tahun 2007 tentang Standar Pengawas Sekolah/ Madrasah. Jakarta.

Peraturan Menteri Pendayagunaan Aparatur Negara dan Reformasi Birokrasi Nomor 21 Tahun 2010 tentang Jabatan Fungsional Pengawas dan Angka Kreditnya. 2010. Jakarta: Departemen PAN dan RB.

Purwanto, Ngalim. 2007. Administrasi dan Supervisi Pendidikan. Bandung: Remaja Rosdakarya.

Wiriaatmadja, Rochiati. 2005. Metode Penelitian Tindakan Kelas. Bandung: Remaja Rosdakarya. 